\title{
Effect of Antibiotic Prophylaxis on Infectious Complications in Patients with Asymptomatic Bacteriuria Undergoing Urologic Surgery
}

\section{Efecto de la profilaxis antibiótica sobre las complicaciones infecciosas en pacientes con bacteriuria asintomática programados a cirugía urológica}

Jorge A. Ramos-Castaneda1® Alberto Ruano-Ravina2,3(-) Javier Osorio-Manrique ${ }^{4}$

Jackeline Barreto-Mora ${ }^{5}$ Angela María Segura-Cardona10 Elkin V. Lemos-Luengas ${ }^{10}$

1 Public Health Observatory, Graduate School, Universidad CES, Medellín, Antioquia, Colombia

2 Department of Preventive Medicine and Public Health, Universidad de Santiago de Compostela, Santiago de Compostela, Galicia, España

${ }^{3}$ Centro de Investigación Biomédica en Red Epidemiología y Salud Pública (CIBERESP), Madrid, Madrid, España

${ }^{4}$ Department of Urology, Centro Especializado de Urología, Neiva, Huila, Colombia

${ }^{5}$ Departamento de Infectología, Grupo de Investigación InfectoControl, Hospital Universitario Hernando Moncaleno Perdomo, Neiva, Huila, Colombia

\author{
Address for correspondence Jorge Andrés Ramos Castañeda, PhD, \\ Graduate School, Universidad CES, Calle 10A 22-04, Medellín, \\ Antioquia, Colombia \\ (e-mail: jormos2806@gmail.com; ramos.jorge@uces.edu.co).
}

Urol Colomb 2021;30(3):e157-e164.
Abstract

\section{Keywords}
- asymptomatic bacteriuria
- urinary tract infection
- bacteremia
- sepsis
- surgical wound infection
- urologic surgical procedures
- urologic surgery

Objectives To identify the effect of duration of surgical antibiotic prophylaxis (SAP) and other variables on infectious postsurgical complications in patients with asymptomatic bacteriuria (ASB) undergoing urological surgery.

Methods We conducted an observational study of a cohort of patients with ASB scheduled for urologic surgery at three health service providers in Colombia. The study population comprised all patients with planned urologic surgery who had ASB prior to surgery from April 2018 to January 2019. The intervention evaluated was the duration of preoperative SAP, and the outcome variable was the development of any postoperative infectious complications for up to 30 days after the procedure.

Results The present study included 184 patients with ASB scheduled for urologic surgery.

The median duration of preoperative SAP $(p=0.49)$ or of 1 dose SAP (risk ratio $[R R]=1.24$; $95 \%$ confidence interval $[\mathrm{Cl}]: 0.45-3.39$ ) were not statistically different in patients with postsurgical infectious complications. Infectious complications were more frequent among patients with benign prostatic hyperplasia $(R R=6.57 ; 95 \% \mathrm{Cl}$ : received

August 19, 2020

accepted after revision

January 21, 2021
DOI https://doi.org/

10.1055/s-0041-1730320.

ISSN 0120-789X.

e ISSN 2027-0119.
(C) 2021. Sociedad Colombiana de Urología. All rights reserved. This is an open access article published by Thieme under the terms of the Creative Commons Attribution-NonDerivative-NonCommercial-License, permitting copying and reproduction so long as the original work is given appropriate credit. Contents may not be used for commercial purposes, or adapted, remixed, transformed or built upon. (https://creativecommons.org/ licenses/by-nc-nd/4.0/)

Thieme Revinter Publicações Ltda., Rua do Matoso 170, Rio de Janeiro, RJ, CEP 20270-135, Brazil 


\author{
Resumen \\ Palabras clave \\ - bacteriuria \\ asintomática \\ - infección del tracto \\ urinario \\ - bacteriemia \\ - sepsis \\ - infección de la \\ herida quirúrgica \\ - procedimientos \\ quirúrgicos \\ urológicos \\ - cirugía urológica
}

1.98-21.76) and hospitalization in the preceding 3 months $(\mathrm{RR}=8.32 ; 95 \% \mathrm{Cl}$ : 2.69-25.71).

Conclusion One dose of antimicrobial therapy is sufficient to avoid infectious complications in patients with ASB. There were other factors associated with postsurgical infectious complications, such as benign prostatic hyperplasia and hospitalization in the preceding 3 months.

Objetivos Identificar el efecto de la duración de la profilaxis antibiótica quirúrgica (PAQ) y otras variables sobre las complicaciones infecciosas posquirúrgicas en pacientes con bacteriuria asintomática (BA) sometidos a cirugía urológica.

Métodos Se realizó un estudio observacional de una cohorte de pacientes con BA programados para cirugía urológica en tres instituciones de salud en Colombia. La población de estudio comprendió a todos los pacientes programados para cirugía urológica y con BA en el periodo de Abril del 2018 a Enero 2019. La intervención evaluada fue la duración de la PAQ preoperatoria, y la variable de resultado fue el desarrollo de cualquier complicación infecciosa posoperatoria hasta 30 días después del procedimiento.

Resultados El estudio incluyó a 184 pacientes con BA programados para cirugía urológica. La mediana de duración de la PAQ preoperatoria $(p=0,49)$ o 1 dosis de PAQ (razón de riesgo [RR]: 1,24; intervalo de confianza [IC] del 95\%: 0,45 a 3,39) no fueron estadísticamente diferentes en pacientes con complicaciones infecciosas posquirúrgicas. Las complicaciones infecciosas fueron más frecuentes entre los pacientes con hiperplasia prostática benigna (RR: 6,57; IC del 95\%: 1,98 a 21,76) y hospitalización en los 3 meses anteriores (RR: 8,32; IC del 95\%: 2,69 a 25,71).

Conclusión Una dosis de terapia antimicrobiana es suficiente para evitar complicaciones infecciosas en pacientes con BA. Hubo otros factores asociados con complicaciones infecciosas posquirúrgicas, como hiperplasia prostática benigna y hospitalización en los tres meses anteriores.

\section{Introduction}

Asymptomatic bacteriuria (ASB) is defined as isolation of bacteria in the urine of an individual without signs or symptoms of urinary tract infection. ${ }^{1}$ Its incidence varies among different population groups, ranging from 7 to $27 \%$ in diabetic individuals to between 1.9 and $9.5 \%$ in pregnant women and between 1 and 5\% in premenopausal women. Asymptomatic bacteriuria is also frequently found in persons with spinal cord injury (between $23 \%$ and $89 \%$ ), ${ }^{2}$ users with indwelling urethral catheters, and patients scheduled for urologic surgery. ${ }^{3,4}$

According to the recommendation contained in the Guidelines on Urological Infections, ASB should not be treated, except in pregnant women, since it reduces the risk of pyelonephritis and premature births; and in patients prior to urological surgery with anticipated mucosal disruption, in view of the risk of presenting with infectious complications such as bacteremia, sepsis, or urinary tract infection. ${ }^{1,3,5-9}$ However, the duration of surgical antibiotic prophylaxis (SAP) has not been clearly established, due to the lack of studies that compare different antibiotic initiation times. $^{10}$
Initially, in 2005, the Infectious Diseases Society of America (IDSA) guidelines recommended a short treatment, without specifying the number of days. ${ }^{1}$ More recently, the 2017 urologic infection guidelines recommend that ASB should be treated prior to endourologic procedures that involve mucosal disruption, although, once again, without specifying the duration of antibiotic treatment. ${ }^{8}$ The IDSA 2019 ASB guidelines suggest a short course of 1 or 2 doses, as opposed to prolonged antibiotic treatment, based on 2 clinical trials that compared single- to multiple-dose long-term therapy. ${ }^{11}$

The lack of studies targeted at evaluating the optimal duration of SAP in patients with ASB means that the duration of antibiotic treatment in urology has not become a standard scientific practice. ${ }^{12}$ Furthermore, the studies that have been conducted have proposed initiating prophylaxis anywhere from 1 to 7 days prior to the procedure, without ascertaining differences in terms of the outcome for each initiation time, ${ }^{7}$ thereby potentially generating improper use of antibiotics. ${ }^{13}$

Bearing in mind that $>30 \%$ of the patients with planned urologic procedures have $\mathrm{ASB},{ }^{14}$ and that this condition poses a risk factor for postsurgical infectious complications, 
it is essential to ascertain the effect of the duration of SAP prior to these procedures.

The aim of the present study was to analyze the effect of the duration of antibiotic prophylaxis and of other variables on postsurgical infectious complications in a cohort of patients with ASB undergoing urological procedures.

\section{Methods}

\section{Study Type and Study Population}

We conducted an observational study of a cohort of patients with ASB scheduled for urologic surgery at three median- to high-complexity hospitals, situated in two cities in Colombia. We included patients undergoing urological surgery from April 2018 to January 2019, and who had been screened to detect ASB prior to surgery. The intervention evaluated was the duration of preoperative SAP.

Asymptomatic bacteriuria was defined as a bacterial isolate in a voided urine sample having a count $>10^{\wedge} 5(\mathrm{CFU} / \mathrm{ml})$, assessed as being from a person who does not exhibit signs or symptoms of urinary tract infection. ${ }^{15}$ The following urologic procedures were included: tumors of the bladder or the urethra, open prostatectomy, transurethral resection of the prostate, ureterolithotomy, nephrolithotomy, and ureterorenoscopy. Patients with immunosuppression secondary to glucocorticoid use, under radiotherapy or chemotherapy treatment, with urinary tract infections, as well as those $<18$ years old, were excluded.

The antibiotic regimen was established from the date of detection of ASB until 30 days after surgery or the development of postsurgical infectious complication. Patients received antibiotic prophylaxis as follows: preoperatively, considering the isolated micro-organism and its susceptibility profile; and perioperatively between 30 and 60 minutes before the procedure, according to the institutional protocol. The duration of antibiotic treatment prior to surgery was empirically determined by the urologist or by an infectious disease physician. All patients underwent the following 2stage follow-up: stage 1 , by telephone at 15 days after the intervention; and stage 2, 30 days after surgery.

\section{Dependent and Independent Variables}

The outcome variable was the development of any postoperative infectious complications, whether in the form of surgical wound infection, urinary tract infection, bacteremia or sepsis, in line with the Centers for Disease Control and Prevention (CDC) criteria. $^{15,16}$ Infectious complications were captured by the principal investigator during followup and/or at the postoperative monitoring appointment. All cases were confirmed by an infectious disease physician external to the study and blinded to the duration of the SAP.

The main independent variable was the duration of preoperative SAP. Other independent variables were gender, age, arterial hypertension, diabetes mellitus, urological cancers, nephrolithiasis, and benign prostatic hyperplasia (HPB). Additionally, data were also gathered on the site where SAP was received and its duration in the postoperative period (POP), prior manipulation of the urinary tract (surgery or endoscopic procedure) in the preceding 3 months, 8,14 antibiotic use in the preceding 3 months, type of urologic intervention, microorganism isolated, multiresistant micro-organism, ${ }^{17}$ as well as hospitalization in the preceding 3 months.

All isolates were identified by different clinical laboratories using the standard method. The susceptibility profile was defined by reference to the Clinical \& Laboratory Standards Institute (CLSI) cutoff values.

\section{Statistical Analysis}

The independent variables were compared considering the development of postsurgical infectious complications. To establish significant differences with the categorical variables, the chi-squared test was used; numerical variables were compared using the Mann-Whitney U-test statistic; and the risk ratios (RRs) with their $95 \%$ confidence intervals (CIs) were calculated for the independent variables. A log-binomial regression model was fitted for explanatory purposes, in which we included the confounding variables; the interactions; and those identified by other studies as having a degree of clinical importance, which proved to be statistically significant. All data analyses were performed using the RStudio 3.5 software package (R Foundation, Vienna, Austria). ${ }^{18}$

\section{Ethical Considerations}

The present study was submitted to and approved by the Universidad CES University research ethics committee (Record no. 123, Study 631), and by the ethics committees of the respective participating institutions. The main investigator entered into a confidentiality agreement with the institutions. All patients signed an informed consent form to participate in the study.

\section{Results}

A total of 184 patients with ASB underwent urological surgeries. Most patients were males $(n=114 ; 61.96 \%)$ with BPH $(n=76 ; 41.30 \%)$. Arterial hypertension was the most frequent comorbidity ( $n=57 ; 30.98 \%$ ). The median age was 63 years old (range: 18 to 88 years old). The two main microorganisms identified were Klebsiella pneumoniae $(n=36$; $19.56 \%)$ and Escherichia coli $(n=70 ; 38.04 \%)$. Micro-organisms resistant to $\geq 3$ groups of antibiotics were identified in $41.85 \%$ ( $n=77)$ of the patients.

In this cohort, the density of incidence of postsurgical infectious complications was 4.27 per thousand patients/day, and the proportion of the incidence was $11.96 \%$. Half of the patients received $>5$ days of antibiotics as prophylaxis in the preoperative period, with 29 days as the maximum. The most used antibiotics in preoperative SAP were fluoroquinolones $(n=58 ; 31.18 \%)$ and aminoglycosides ( $n=28 ; 15.05 \%) ; 15.22 \%(n=28)$ of the patients received 1 dose antimicrobial therapy before the procedure. Surgical antibiotic prophylaxis was extended across the POP in $73.66 \%$ of the patients $(n=137)$ for a median of 7 days postoperatively ( Table $\mathbf{1}$ ).

The duration of SAP was found to have no effect on postsurgical infectious complications. The median duration 
Table 1 Effect of antibiotic prophylaxis on postsurgical infectious complications in patients with asymptomatic bacteriuria $(n=184)$

\begin{tabular}{|l|l|l|l|}
\hline DATA & INFECTION $(\boldsymbol{n}=22)$ & p-value & Crude RR (95\%Cl) \\
\hline SAP ADMINISTRATION SETTING & & & \\
\hline Ambulatory care & $6(6.59)$ & 0.04 & 0.38 (0.16-0.93) \\
\hline Hospital care & $16(17.20)$ & Ref. & Ref. \\
\hline DURATION OF PREOPERATIVE SAP & & & \\
\hline One dose & $4(14.29)$ & 0.75 & $1.24(0.45-3.39)$ \\
\hline > One dose & $18(11.54)$ & Ref. & Ref. \\
\hline TYPE OF PREOPERATIVE SAP & & & \\
\hline Fluoroquinolones & 5 & & \\
\hline Aminoglycosides & 4 & & \\
\hline Two antibiotics & 3 & & \\
\hline Narrow-spectrum cephalosporins & 2 & & \\
\hline Nitrofurantoin & 0 & & \\
\hline Carbapenems & 3 & & \\
\hline Extended-spectrum cephalosporins & 2 & & \\
\hline Penicillins + beta-lactamase inhibitors & 2 & & \\
\hline Penicillins & 1 & & \\
\hline Antipseudomonal penicillins & 0 & & \\
\hline Phosphonic acids & 0 & & \\
\hline Folate antagonists & 0 & & \\
\hline Monobactams & 0 & & \\
\hline Polymyxins & 0 & & \\
\hline SAP IN THE POP & & & \\
\hline No & $5(10.64)$ & & \\
\hline Yes & $17(12.41)$ & & \\
\hline
\end{tabular}

Abbreviations: $\mathrm{Cl}$, confidence interval; POP: Postoperative period; RR, risk ratio; SAP: surgical antimicrobial prophylaxis.

of preoperative SAP $(p=0.49)$ and 1 -dose SAP $(R R=1.24$ 95\%CI: 0.45-3.39) were not statistically different in patients with postsurgical infectious complications. Similarly, SAP in the POP did not display significant differences in terms of infected patients ( $\mathrm{RR}=1.17 ; 95 \% \mathrm{CI}$ : 0.45-2.99) (-Table 1). Administration of preoperative SAP on an ambulatory basis was greater among patients who did not develop infectious complications ( $R R=0.38$; 95\%CI: 0.16-0.93) (-Table 1 ).

Postsurgical infectious complications were greater among patients with diabetes $(\mathrm{RR}=2.50 ; 95 \% \mathrm{CI}$ : 1.09-5.76), $\mathrm{BPH}$ $(\mathrm{RR}=3.05$; 95\%CI: $1.30-7.11)$, hospitalization in the preceding 3 months ( $R R=4.94 ; 95 \% C I: 1.91-12.81)$, indwelling urinary catheters ( $R R=2.30 ; 95 \% \mathrm{CI}: 1.06-4.97)$, as well as endourological intervention in the preceding 3 months (RR $=2.23$; 95\%CI: 1.03-4.84). Asymptomatic bacteriuria with multidrug-resistant bacteria was present in $41.40 \%$ of the patients, and its incidence was higher in infected patients (50.0 versus $40.74 \%$ ); however, without statistical significance $(\mathrm{RR}=1.39 ; 95 \% \mathrm{CI}$ 0.64-3.04) (-Table 2 ).

The factors found by the multivariate analysis to be associated with postsurgical infectious complications were
$\mathrm{BPH}(\mathrm{RR}=6.57 ; 95 \% \mathrm{CI}: 1.98-21.76)$ and hospitalization in the preceding 3 months ( $R R=8.32 ; 95 \% C I$ : 2.69-25.71). Surgical antibiotic prophylaxis-related variables were not included in the model due to lack of statistical significance (-Table 3).

\section{Discussion}

This is the first prospective study in Latin America to assess the effect of duration of SAP on postsurgical infectious complications in patients with ASB scheduled for urologic surgery. The results indicate that one dose of antimicrobial therapy preoperatively is sufficient to prevent postsurgical infectious complications in patients with ASB. We found other factors associated with postsurgical infectious complications, such as benign prostatic hyperplasia and hospitalization in the preceding 3 months. Also, the administration of preoperative SAP on an ambulatory basis was greater among patients who did not develop infectious complications.

The IDSA guideline for the management of ASB (2019) ${ }^{11}$ recommends that, in patients with planned urologic 
Table 2 Factors associated with postsurgical infectious complications in patients with asymptomatic bacteriuria $(n=184)$

\begin{tabular}{|c|c|c|c|}
\hline DATA & INFECTION $(n=22)$ & p-value & Crude RR (95\%Cl) \\
\hline \multicolumn{4}{|l|}{ Gender } \\
\hline Female & $5(7.14)$ & 0.11 & $0.48(0.18-1.24)$ \\
\hline Male & $17(14.91)$ & Ref. & Ref. \\
\hline \multicolumn{4}{|l|}{ AGE (Years Old) } \\
\hline$>63$ years & $12(14.10)$ & 0.40 & $1.40(0.64-3.07)$ \\
\hline$\leq 63$ years & $10(10.10)$ & Ref. & Ref. \\
\hline \multicolumn{4}{|l|}{ HTA } \\
\hline Yes & $8(13.60)$ & 0.64 & $1.21(0.54-2.73)$ \\
\hline No & $14(11.20)$ & Ref. & Ref. \\
\hline \multicolumn{4}{|l|}{ DM } \\
\hline Yes & $6(25.00)$ & 0.03 & $2.50(1.09-5.76)$ \\
\hline No & $16(10.00)$ & Ref. & Ref. \\
\hline \multicolumn{4}{|l|}{ UROLOGIC CANCER } \\
\hline Yes & 1 (7.69) & 0.62 & $0.63(0.09-4.29)$ \\
\hline No & $21(12.28)$ & Ref. & Ref. \\
\hline \multicolumn{4}{|l|}{ NEPHROLITHIASIS } \\
\hline Yes & $8(13.60)$ & 0.64 & $1.21(0.54-2.73)$ \\
\hline No & $14(11.20)$ & Ref. & Ref. \\
\hline \multicolumn{4}{|l|}{$\mathrm{BPH}$} \\
\hline Yes & $15(19.74)$ & $<0.01$ & $3.05(1.30-7.11)$ \\
\hline No & $7(6.48)$ & Ref. & Ref. \\
\hline \multicolumn{4}{|c|}{ PRIOR ENDOUROLOGICAL INTERVENTION* } \\
\hline Yes & $10(20.0)$ & 0.05 & $2.23(1.03-4.84)$ \\
\hline No & $12(8.95)$ & Ref. & Ref. \\
\hline \multicolumn{4}{|l|}{ PRIOR SURGERY* } \\
\hline Yes & $5(14.71)$ & 0.58 & $1.30(0.51-3.27)$ \\
\hline No & $17(11.33)$ & Ref. & Ref. \\
\hline \multicolumn{4}{|c|}{ INDWELLING URINARY CATHETER } \\
\hline Yes & $10(20.41)$ & 0.03 & $2.30(1.06-4.97)$ \\
\hline No & $12(8.89$ & Ref. & Ref. \\
\hline \multicolumn{4}{|l|}{ URETERAL STENT } \\
\hline Yes & $1(4.76)$ & 0.28 & $0.37(0.05-2.61)$ \\
\hline No & $21(12.88)$ & Ref. & Ref. \\
\hline \multicolumn{4}{|l|}{ PREVIOUS HOSPITALIZATION* } \\
\hline Yes & $17(22.67)$ & $<0.01$ & $4.94(1.91-12.81)$ \\
\hline No & $5(4.59)$ & Ref. & Ref. \\
\hline $\begin{array}{l}\text { ANTIBIOTIC USE* } \\
\text { Yes }\end{array}$ & $16(15.69)$ & 0.08 & $2.14(0.88-5.23)$ \\
\hline No & $6(7.32)$ & Ref. & Ref. \\
\hline \multicolumn{4}{|c|}{ REASON FOR UROLOGIC INTERVENTION } \\
\hline Tumor & $1(14.28)$ & Ref. & Ref. \\
\hline Urologic cancer & $1(5.88)$ & 0.51 & $0.41(0.03-5.70)$ \\
\hline Hydronephrosis & $2(8.33)$ & 0.55 & $0.58(0.06-5.52)$ \\
\hline Benign Prostatic Hyperplasia & $13(18.57)$ & 1.0 & $1.30(0.20-8.52)$ \\
\hline
\end{tabular}


Table 2 (Continued)

\begin{tabular}{|l|l|l|l|}
\hline DATA & INFECTION $(\boldsymbol{n}=\mathbf{2 2})$ & $p$-value & Crude RR $(95 \% \mathrm{CI})$ \\
\hline Urinary incontinence & 0 & NA & NA \\
\hline Lithiasis & $5(10.0)$ & 0.56 & $0.70(0.09-5.15)$ \\
\hline NNIS SURGICAL RISK & & & \\
\hline 1 & $17(11.80)$ & Ref. & Ref. \\
\hline 2 & $4(10.26)$ & 1.0 & $0.87(0.31-2.42)$ \\
\hline 3 & $1(100)$ & 0.12 & NA \\
\hline MULTIDRUG-RESISTANT BACTERIA & & & \\
\hline No & $11(14.30)$ & 0.41 & $1.39(0.64-3.04)$ \\
\hline Yes & $11(10.3)$ & Ref. & Ref. \\
\hline
\end{tabular}

Abbreviations: AHT: arterial hypertension; CI: Confidence interval; DM: diabetes Mellitus; BPH: benign prostatic hyperplasia; NNIS: national nosocomial infections surveillance; RR: risk ratio.

* In the last 3 months.

Table 3 Regression analysis of factors associated with postsurgical infectious complications in patients with asymptomatic bacteriuria $(n=184)$

\begin{tabular}{|l|l|l|}
\hline $\begin{array}{l}\text { ASSOCIATED } \\
\text { FACTORS }\end{array}$ & $\begin{array}{l}\text { Crude RR } \\
(95 \% \mathrm{Cl})\end{array}$ & Adjusted RR (95\%CI) \\
\hline AGE (years old) & & \\
\hline$>63$ & $\begin{array}{l}1.40 \\
(0.64-3.07)\end{array}$ & $0.30(0.09-0.97)$ \\
\hline$\leq 63$ & Ref. & Ref. \\
\hline $\begin{array}{l}\text { DIABETES } \\
\text { MELLITUS }\end{array}$ & & \\
\hline Yes & $\begin{array}{l}2.50 \\
(1.09-5.76)\end{array}$ & $2.27(0.90-5.69)$ \\
\hline No & Ref. & Ref. \\
\hline BPH & $\begin{array}{l}\text { (1.05 } \\
\text { Yes }\end{array}$ & $6.57(1.98-21.76)$ \\
\hline No & Ref. & Ref. \\
\hline $\begin{array}{l}\text { PRIOR } \\
\text { HOSPITALIZATION }\end{array}$ & $\begin{array}{l}4.94 \\
(1.91-12.81)\end{array}$ & $8.32(2.69-25.71)$ \\
\hline Yes & Ref. & Ref. \\
\hline No & & \\
\hline
\end{tabular}

Abbreviations: $\mathrm{Cl}$, confidence interval; $\mathrm{BPH}$ : benign prostatic hyperplasia; RR, risk ratio.

1. Age-adjusted RR, diabetes mellitus, benign prostatic hyperplasia, and hospitalization in the previous 3 months.

procedures, SAP should be administered as a short (one or two doses) rather than as a prolonged course. This recommendation is based on the findings of two clinical trials that compared the incidence of infectious complications in two groups, one that received a single dose, and another that was prescribed a longer regimen. ${ }^{19}$

In a clinical trial, Sayin Kutlu et al. ${ }^{19}$ compared 59 patients with ASB who were scheduled for urologic surgery. They were divided into 2 groups: the $1^{\text {st }}$ group received a single dose of antibiotics 30 to 60 minutes prior to surgery; the $2^{\text {nd }}$ group comprised patients who received antibiotic treatment until the urine culture tested negative ( $8 \pm 3$ days). In this study, no patient developed postsurgical infectious complications, yet the group of patients that received a prolonged antibiotic regimen registered a longer hospital stay $(p<0.01)$ and higher antibiotic treatment costs $(p<0.01)$. Our study compared all patients with ASB, taking into account different SAP duration modalities, showing that, as yet, there is no standard practice in place. Surgical antibiotic prophylaxis duration was also found to have no effect on the prevention of postsurgical infectious complications, results similar to those reported by Sayin Kutlu et al. ${ }^{19}$

Another prospective study evaluated 60 patients with ASB and spinal cord injury scheduled for urologic endoscopic procedures. ${ }^{20}$ These patients were also divided into 2 groups: the first group of 35 patients received a single dose of antibiotic 30 minutes before the procedure; the second group of 25 patients received a regimen of 3 to 5 days. In this cohort, one patient in each group developed some postsurgical infectious complication, but the costs of antibiotic treatment and preoperative anxiety were lower in the group that received a single dose. ${ }^{19}$ Diagnostic cystoscopy accounted for most procedures included, $98.3 \%$ of the patients were male, and the study objective was not to compare infectious complications, but rather to compare the quality of life of the patients. In contrast, our study used a larger patient sample, included several urologic procedures, and focused especially on comparing postsurgical infectious complications.

We found that there are other factors that increase the risk of postsurgical infectious complications, such as comorbidities and having undergone hospitalization in the 3 months immediately preceding the procedure. These factors have already been described by previous studies. ${ }^{4,14}$ In a cohort of 2.201 patients scheduled for urologic procedures, Cai et al. found that patient comorbidities increased the risk of infectious complications. ${ }^{14}$ Similarly, our study also showed that $\mathrm{BPH}$ was more frequent in patients who developed postsurgical infectious complication. 
The fact that a patient has been hospitalized is a factor that is associated with healthcare-related infections, due to exposure to invasive devices, contact with healthcare personnel, and use of antibiotics. ${ }^{21,22}$ In our study, postsurgical infectious complications were greater among patients who underwent hospitalization in the 3 months immediately preceding the urologic procedure.

Providing evidence to show that the duration of SAP has no influence on the risk of infectious complications has a direct impact on health care costs and prudent antibiotic use. ${ }^{23}$ Among the strengths of the present study is the fact that it is the first prospective multicenter study to compare different SAP initiation times. Furthermore, since the participants were selected consecutively, the study can be considered as being free of selection bias. The evaluation of the outcome was subjected to a second evaluation by an infectious disease physician external to the study, who was biased toward the duration of SAP. Lastly, both pre- and postoperative antibiotic use were considered.

The present study has some limitations. Isolates were identified using the standard method, albeit at different clinical laboratories, in view of the fact that patient care depends on each institution. The small sample size did not allow for analysis by subgroup with a breakdown by urologic procedure or type of infectious complication. Even so, this ranks as the prospective study with the largest-sized sample to be conducted in Latin America on patients with ASB prior to urologic procedures. Taking into account the fact that urologists participated in the study, they might have prescribed antibiotics appropriately or prescribed wider-spectrum antibiotics, thus constituting a possible selection bias.

Based on these results, it is important to raise three aspects that will have to be studied in greater depth: one, the necessity and cost-effectiveness of screening and treating ASB prior to urologic procedures, bearing in mind the consequences in terms of urinary disbiosis and bacterial resistance; two, the need to consider whether the SAP received by patients in the perioperative period is sufficient to control the risk, as has been highlighted by some researchers ${ }^{14,24}$; lastly, performing a study to evaluate the association between postsurgical infectious complications with benign prostatic hyperplasia and hospitalization in the preceding 3 months.

\section{Conclusions}

Duration of SAP has no effect on infectious complications. There are other variables that are associated with development of postsurgical infectious complications in patients with ASB scheduled for urologic surgery, such as BPH and hospitalization in the 3 months immediately preceding surgery. Lastly, the patients who did not develop infectious complications had the administration of preoperative SAP on an ambulatory basis.

\section{Funding Statement}

The principal author is beneficiary of the grant 677-2014 COLCIENCIAS and Departamento del Huila.
Conflict of Interests

The authors have no conflict of interests to declare.

Acknowledgment

The leading author is grateful to the Clínica CES, to the Centro Especializado de Urología and to the Hospital Universitario Hernando Moncaleano Perdomo de Neiva.

\section{References}

1 Nicolle LE, Bradley S, Colgan R, Rice JC, Schaeffer A, Hooton TMInfectious Diseases Society of America American Society of Nephrology American Geriatric Society. Infectious Diseases Society of America guidelines for the diagnosis and treatment of asymptomatic bacteriuria in adults. Clin Infect Dis 2005;40(05): 643-654

2 Ospina Galeano IA, Duran AB. Infección Urinaria en Pacientes con Lesión Medular. Urol Colomb 2018;27(01):8-13

3 Nicolle LE. Asymptomatic bacteriuria: when to screen and when to treat. Infect Dis Clin North Am 2003;17(02):367-394

4 Ramos-Castaneda JA, Ruano-Ravina A, Munoz-Price LS, et al. Risk of infection in patients undergoing urologic surgery based on the presence of asymptomatic bacteriuria: A prospective study. Am J Infect Control 2019;47(12):1474-1478

5 Hughes R, Aitken E, Anderson J, Barry C, Benton M. Antenatal care for uncomplicated pregnancies. Natl Inst Health Care Excell2008

6 Lin K, Fajardo KU.S. Preventive Services Task Force. Screening for asymptomatic bacteriuria in adults: evidence for the U.S. Preventive Services Task Force reaffirmation recommendation statement. Ann Intern Med 2008;149(01):W20-4

7 Ramos JA, Salinas DF, Osorio J, Ruano-Ravina A. Antibiotic prophylaxis and its appropriate timing for urological surgical procedures in patients with asymptomatic bacteriuria: A systematic review. Arab J Urol 2016;14(03):234-239

8 Bonkat G, Pickard R, Bartoletti R, et al. EAU Guidelines on urological infections. En: EAU Guidelines, Edn published as the 32nd EAU Annual Meeting, London, EAoUG Office, Editor. 2017

9 Villarraga JDA, Parra JDI, Diaz DA, Cárdenas AM, Chavarriaga J, Godoy MP. Guía de práctica clínica de infección de vías urinarias en el adulto. Rev Urol Colomb J 2018;27(02):126-131

10 Ramos JA, Lemos EV, Ruano-Ravina A. Duration of surgical antibiotic prophylaxis in patients with asymptomatic bacteriuria. Lancet Infect Dis 2017;17(04):370

11 Nicolle LE, Gupta K, Bradley SF, Colgan R, DeMuri GP, Drekonja D, et al. Clinical Practice Guideline for the Management of Asymptomatic Bacteriuria: 2019 Update by the Infectious Diseases Society of America. Clin Infect Dis 2019May 268(10):e83-e110. Doi: $10.1093 /$ cid/ciy1121

12 Mossanen M, Calvert JK, Holt SK, et al. Overuse of antimicrobial prophylaxis in community practice urology. J Urol 2015;193(02): 543-547

13 Ruano-Ravina A, Ramos Castañeda JA. Duración de la profilaxis antibiótica en pacientes con bacteriuria asintomática, ¿evidencia o desconocimiento? (Duration of antibiotic prophylaxis in patients with asymptomatic bacteriuria: evidence or ignorance?). CES Med[Internet]. 1 de julio de 2016 [citado 12 de mayo de 2021];30(01):135-6. Disponible en: https://revistas.ces.edu.co:443/ index.php/medicina/article/view/3720

14 Cai T, Verze P, Palmieri A, et al. Is preoperative assessment and treatment of asymptomatic bacteriuria necessary for reducing the risk of postoperative symptomatic urinary tract infections after urologic surgical procedures? Urology 2017;99:100-105

15 Horan TC, Andrus M, Dudeck MA. CDC/NHSN surveillance definition of health care-associated infection and criteria for specific types of infections in the acute care setting. Am J Infect Control 2008;36(05):309-332 
16 Centers for Disease Control. Surgical Site Infection (SSI) Event. Atlanta: CDC; 2014. 2014

17 Magiorakos A-P, Srinivasan A, Carey RB, Carmeli Y, Falagas ME, Giske CG, et al. Multidrugresistant, extensively drug-resistant and pandrugresistant bacteria: an international expert proposal for interim standard definitions for acquired resistance. Clin Microbiol Infect 2012;18 (03):268-281. Doi: 10.1111/j.1469-0691.2011.03570.x

18 RStudio Team (2020) RStudio: Integrated Development for R. RStudio, PBC, Boston, MA URL. http://www.rstudio.com/

19 Sayin Kutlu S, Aybek Z, Tekin K, et al. Is short course of antimicrobial therapy for asymptomatic bacteriuria before urologic surgical procedures sufficient? J Infect Dev Ctries 2012;6(02):143-147

20 Chong JT, Klausner AP, Petrossian A, et al. Pre-procedural antibiotics for endoscopic urological procedures: Initial experience in individuals with spinal cord injury and asymptomatic bacteriuria. J Spinal Cord Med 2015;38(02):187-192
21 ALfadli M, El-Sehsah EM, Ramadan MAM. Risk factors and distribution of MDROs among patients with healthcare associated burn wound infection. Germs 2018;8(04):199-206

22 Pobiega M, Wojkowska-Mach J, Chmielarczyk A, et al. Molecular characterization and drug resistance of Escherichia coli strains isolated from urine from long-term care facility residents in Cracow, Poland. Med Sci Monit 2013;19: 317-326

23 Ramos-Castaneda JA, Ruano-Ravina A, Salinas DF, Osorio-Manrique J, Segura-Cardona AM, Lemos-Luengas EV. Factors associated with multidrug-resistant bacteria in a cohort of patients with asymptomatic bacteriuria who underwent urological surgery. Am J Infect Control 2019;47(12):1479-1483

24 Cai T, Koves B, Johansen TEB. Asymptomatic bacteriuria, to screen or not to screen - and when to treat? Curr Opin Urol 2017;27(02): $107-111$ 